\title{
Authenticity vs. Inauthenticity in Oscar Wilde's The Importance of Being Earnest
}

\author{
Md. Ibrahim Khalil \\ Lecturer, Department of English \\ Pabna University of Science and Technology, Pabna-6600, Bangladesh \\ ibrahimkhalil@pust.ac.bd
}

DOI: http://doi.org/ 10.36892/ijlls.v3i2.594

\begin{tabular}{|c|c|}
\hline $\begin{array}{l}\text { Received: } \\
\text { 13/05/2021 }\end{array}$ & $\begin{array}{c}\text { Abstract } \\
\text { Unlike other living creatures, human being requires an authentic life to }\end{array}$ \\
\hline $\begin{array}{l}\text { Accepted: } \\
\text { 24/06/2021 }\end{array}$ & $\begin{array}{l}\text { reflect the true self and independence. Due to the limitations and } \\
\text { complicacies of life, either personal or from the surroundings, people } \\
\text { sometimes play inauthentic roles and express inconsistent statements. }\end{array}$ \\
\hline $\begin{array}{l}\text { Keywords: } \\
\text { Earnest, authenticity, } \\
\text { inauthenticity, } \\
\text { true self and } \\
\text { identity, } \\
\text { existentialism }\end{array}$ & $\begin{array}{l}\text { Moncireff frequently change their valid identity and address for } \\
\text { abundant freedom and worldly pleasure. Considering two fundamental } \\
\text { existentialistic concerns such as authenticity and inauthenticity along } \\
\text { with qualitative and descriptive analysis method, the study evaluates } \\
\text { how authentic or inauthentic decisions Algernon and Jack have made to } \\
\text { transform their long carried name, definite identity and diversified } \\
\text { location. It highlights how Wilde's major characters are intertwined } \\
\text { with complicated relationships affecting self-motivated decision, choice } \\
\text { and freedom. Nevertheless, the study takes into account all the self- } \\
\text { contradictory commitments of both Algernon and Jack Worthing and } \\
\text { their ridiculous attitude towards religious perception. Finally, it } \\
\text { inspects the authenticity of the name "Earnest" for what both Cecily } \\
\text { Cardew and Gwendolen Fairfax always feel an inexorable urge and } \\
\text { fervor. }\end{array}$ \\
\hline
\end{tabular}

\section{INTRODUCTION}

Throughout the entire play The Importance of Being Earnest, the name "E-a-r-n-e-s-t" has been used and spelled as "E-r-n-e-s-t" except the last line of the third act. The importance of this study is that it questions the legitimacy of the name "Earnest". The two important protagonists of this play, Jack Worthing and Algernon Moncrieff, agreed to change their names to impress their beloved Gwendolen Fairfax and Cecily Cardew respectively. In this work, their substantial actions have been studied to figure out both authenticity and inauthenticity side by side. Firstly, it argues how Algernon Moncrieff executes his desires and actions to fulfill his freedom and self. Secondly, it concentrates on Jack's astounding struggle to define his valid origin and authentic identity. Consequently, it brings to light what kind of actions and reactions Jack has to receive from the surroundings especially from his beloved Gwendolen's mother, Lady Bracknell. Thirdly, this paper examines the authentic background of Algernon's promise and Jack's fluctuating commitments. Fourthly, it investigates the authenticity of the treatment towards religious values. Finally, this paper figures out substantial points to prove the inauthenticity of the name "Earnest" applying existentialistic approach. 


\section{LITERATURE REVIEW}

Oscar Wilde's The Importance of Being Earnest attracted worldwide attention of literary criticism. Nassaar (2002) remarks, "It is widely acknowledged today that The Importance of Being Earnest is at one level a self-parody in which Wilde reduces the major events and themes of his earlier works to absurdity" (p.78). Later, Nassasr explains the crucial position of Jack Worthing, "In The Importance of Being Earnest the theme of the abused child surfaces again but is treated in an extremely ridiculous, nonsensical manner" (2002, p.79). The formal structure of this play is also important to be noted as Barris (2008) explores, "I do not aim to show that the play is metaphysics or that it justifies this formal structure as appropriate to metaphysics, only that it parallels and displays this structure in its own way" (p. 546). Garland (2012) makes his ground discussing the contest of naming between the heroines, "In Oscar Wilde's The Importance of Being Earnest, male characters name themselves to achieve their desires and female characters name others to exert power and ultimately provide the inevitable happy ending" (p. 272). Lalonde (2005) contextualizes the social criticism remarking the character Lady Bracknell, "I propose that The Importance of Being Earnest allows for two readings; one can assume the role of the narrator of "The Portrait of Mr. W.H." (Wilde) or that of Lady Bracknell. Both readings have their limits and privilege the performance either of class or of sexuality in the play" (p. 659). Shabir (2020) concentrates on Victorian England to figure out questionable human ethics, trivialities and showy attitude. He demonstrates how Victorian people lose their moral values, "The society in Victorian England is marked by its aristocracy, class consciousness and elitism, scantiness of human values, materialistic endeavors, hypocrisy and chauvinism" (p.81). But here, this study investigates Wilde's The Importance of Being Earnest from a new dimension existentialism exploring several issues based on two basic existential terms "Authenticity" and "Inauthenticy".

\section{THEORETICAL BACKGROUND}

The existentialist philosophers always search for an authentic and meaningful life applying free will, choice and self-selective decision. The term "Authenticity" is the core feature of existentialism as Carman (2006) explains, "The concept of authenticity is one of the most important and fruitful ideas to emerge from the existential tradition in philosophy, especially in the works of Kierkegaard, Heidegger, and Sartre" (p. 229). In the heart of existentialism there appears several queries based on humanism. Thomas R. Flynn (2006) introduced the factual basis of authenticity, "The factual basis of authenticity brings us back to the basic question of humanism: What is the human being? What, if anything, distinguishes us from the rest of nature?"(p. 65) Interetingly, the term "Authentitiy" is quite synonymous with individualism:

Authenticity is a feature of the existentialist individual. In fact, existential individuality and authenticity seem to imply one another. One is no more born an individual (in the existentialist sense) than is one born authentic. To be truly authentic is to have realized one's individuality and vice versa (Flynn, 2006, p. 74).

Basically, authenticity echoes the true self of an individual. Carman points out that Heidegger used the word "authentic" (eigentlich) freely in his work magnum opus, Being and Time (2006, p. 233). Panza and Gregory (2008) explains that the term "authentic" describes something real or genuine and the term "inauthentic" designates something artificial, counterfeit, or fake (p. 87). Flynn (2006) added both the views of Nietzsche and Sartre, "This is a form of Nietzsche's prescription to 'become what you are'. It is a matter of living the truth about ourselves, about our condition as human beings. The inauthentic person, in Sartre's view, is living a lie" (p. 64). In terms of thing and person, authenticity does not give equal sense. "The authenticity of a thing depends on how some other entity represents it" (Panza and Gregory, 2008, p. 91). In addition, two basic requirements of the authenticity of a thing are: Firstly, a thing is authentic when it matches the template or standard. Secondly, a thing is inauthentic when it doesn't match that template or standard (Panza and Gale, 2008, p. 90). John Macquarrie (1973) defined inauthentic concern remarking the destruction of human social bondage, "Practically all existentialists, even those who lay most stress on the notions of 'I and Thou' and being-with-others, are agreed that human social relations, as we normally find them, are sadly distorted. The everyday being-with-others is inauthentic" (p. 118). Contrarily, an authentic person requires something else, "The authenticity of a person depends on how that person uses or represents himself through living. So if someone is by nature an individual, but he lives only by the opinions of 
others, he's misrepresenting what he is and failing to be authentic" (Panza and Gale, 2008, p. 91).Carman (2006) focused Kierkegaard's concern of selfhood based on Christian faith, "A self that could embark on such a focused, wholehearted commitment to something in this life, while nevertheless treating it as eternally valuable, would be a genuine or authentic self, exemplified according to Kierkegaard in the ideal of Christian faith" (Carman, 2006, p. 230). Flynn (2006) notes Nietzsche's concept of authenticity, "Authenticity is often seen as an ethical gyroscope serving to help one keep one's bearings in a state of Nietzschean moral free-fall. If the authentic person is ethically 'creative' and has ventured out beyond the last lighthouse of ethical security" (p. 78). On the other hand, Sartre talked about self-defined choice and non-self-identity to explain his idea of inauthentic flight, "Sartre argues that our original coice is our futile pursuit of being consciously self-identical. We have seen that the quest for identity is on a collision course with our consciousness as non-selfidentical" (Flynn, 2006, p. 76). Moreover, Macquarrie (1973) clarifies both authentic being-withothers and inauthentic being-with-others:

Authentic being-with-others is precisely that mode of relation to the other that promotes existence in the full sense; that is to say, it lets the human stand out as human, in freedom and responsibility. On the other hand, inauthentic being-with-others suppresses the genuinely human and personal. Whatever kind of relation to the others depersonalizes and dehumanizes is an inauthentic one (p.121).

On the basis of this theoretical framework, this research explores both the concept of authenticity and inauthenticity in Oscar Wilde's play The Importance of Being Earnest.

\section{FINDINGS AND DISCUSSION}

Oscar Wilde's play The Importance of Being Earnest (1895) mirrors both the views of authenticity and inauthenticity. The study has investigated and discussed these following issues.

\subsection{Searching for Authenticity in True Self and Identity}

Algernon Moncrieff, one of the major characters of the play, wants to lead an authentic life. On the way to meet his true self, he never cares anything either good or evil. Even he does not feel to count what other people may think of him. Friedrich Nietzsche's observation is importantly relevant here, "As Friedrich Nietzsche once put it, the goal is to "become what you already are!" It means representing yourself in a way that can be considered genuine, which means embracing the fact that you must confront the world in your own individual way' (Panza and Gregory, 2008, p. 87). Consequently, Algernon dislikes the traditional ideals of the society. He remains busy to satisfy his "Self". During playing the piano, he maintains his own way, "I don't play accurately-anyone can play accurately-but I play with wonderful expression. As far as the piano is concerned, sentiment is my forte. I keep science for life" (Wilde, 2016, p. 11). Unlike others, he rejects the conventional perception of romantic love proposal:

I really don't see anything romantic in proposing. It is very romantic to be in love. But there is nothing romantic about definite proposal. Why, one may be accepted. One usually is, I believe. Then the excitement is all over. The very essence of romance is uncertainty. If ever I get married, I'll certainly try to forget the fact (Wilde, 2016, p. 13).

It is pertinent to note that Algernon is strongly concerned about his beliefs, confident on his own understanding and self-defined choice. Flynn (2006) acknowledges the urge of own choice, "We are challenged to own up to our self-defining choices; to make them our own and consequently to become selves by acknowledging what we are" (p.64). Interestingly, these ideas have been reflected in Algernon's decisions and actions. His understanding towards life is that everything should be free and comfortable. There should be nothing restricted in the modern culture, "Oh! it is absurd to have a hard and fast rule about what one should read and what one shouldn't. More than half of modern culture depends on what one shouldn't read" (Wilde, 2016, p.15). But the crucial fact is that Algernon belongs to a Victorian period. Therefore, he has to face the challenges of Victorian ideals, values and norms. Shabir (2020) puts his argument against the so called social trivialities confronting Wilde's sharp observation of Victorian society: 
The drive for social and material advancement had corrupted the heart and soul of man. People were judged by their wardrobe, their dinning manners, by their way of talking and on the basis of other petty issues (P. 81).

Algernon knows all the social dogmas and severe restrictions. Therefore, he has created another fictional character Bunbary to execute his desires and wishes. His self has become so strong that Jack Worthing fails to convince. When Jack advises to get rid of the duel characters, Algernon immediately protests, "Nothing will induce me to part with Bunbury, and if you ever get married, which seems to me extremely problematic" (Wilde, 2016, p. 18). He is not serious about relationship but food stuffs, "I hate people who are not serious about meals. It is so shallow of them" (Wilde, 2016, p.19). The narrator remarks Algernon's carelessness about relationship:

My dear boy, I love hearing my relations abused. It is the only thing that makes me put up with them at all. Relations are simply a tedious pack of people, who haven't got the remotest knowledge of how to live, nor the smallest instinct about when to die (Wilde, 2016, p. 29).

Algernon thinks that if he wants to satisfy the society, he will fail to fulfill his wish and self. Therefore, he openly declared, "Cecily is the sweetest, dearest, prettiest girl in the whole world. And I don't care two pence about social possibilities" (Wilde, 2016, p. 67). Understanding Algernon's position his aunt Lady Bracknell responds, "Never speak disrespectfully of the society, Algernon. Only people who can't get into it do that" (Wilde, 2016, p. 68). Conforming authentic life, sometimes the individual breaks the relationship with inauthentic system. Macquarrie (1973) reports, "One type holds that the individual break with inauthentic society is the first step towards being free for genuine relations with others" (p. 122). Algernon's statement proves his straightforward individuality, "I don't care for anybody in the whole world but you. I love you, Cecily" (Wilde, 2016, p. 47). On the other hand, Jack usually comes to city in order to search his self. In the countryside, he has to play the actions of a guardian. Therefore he cannot execute his own wishes and desires. Being bored to country life, Jack needs a congenial platform to prosper his will. This background forces him to create a fictional brother named Earnest. In the name of Earnest he usually visits Algernon's flat and other places to enjoy his life. The narrator remarks it in a conversation between Algernon and Jack:

ALGERNON: How are you, my dear Ernest? What brings you up to town?

JACK: Oh, Pleasure, pleasure! (Wilde, 2016, p. 12)

Afterwards, Jack clarified his primary purpose and motives. Wilde pointed out Jack's comments:

My dear Algy, I don't know whether you will be able to understand my real motives. You are hardly serious enough. When one is placed in the position of guardian, one has to adopt a very high moral tone on all subjects. It's one's duty to so. And as a high moral tone can hardly be said to conduce very much to either one's health and one's happiness (Wilde, 2016, p. 17).

Along with earthly pleasure, Jack has another intention to visit city frequently. Jack addressed his love, "I am in love with Gwendolen. I have come up to town expressly to propose to her" (Wilde, 2016, p. 13). Despite having great dedication to his beloved, Jack cannot execute his decision due to the lack of freedom. He has to depend on Lady Bracknell's consent. Gwendolen Fairfax also loves Jack in the name of Earnest. In order to acknowledge Gwendolen's impression towards Jack, the narrator reported her comments, "Your Christian name has an irresistible fascination. The simplicity of your character makes you exquisitely incomprehensible to me" (Wilde, 2016, p. 32). Yet, she is afraid of her mother's motivation. She says, "Ernest, we may never be married. From the expression on mamma's face I fear we never shall. Few parents nowadays pay any regard to what their children say to them" (Wilde, 2016, p. 31). Therefore, both Jack and Gwendolen have to depend on Lady Bracknell's choice and decision.

Another important point of authenticity is that it creates severe problems in life. Panza and Gregory argued, "Existentialists tend to agree that authenticity causes a lot of personal discomfort, and for the most part, human beings tend to want to take the easy path in life" (99). In order to live an authentic life, like Algernon Jack did have plain prosperity. His fictional brother Earnest made his life complicated. Before Cecily, he had depend on falsehood. He lied one after another. When Cecily became interested in Earnest, he planned to kill him. Besides, he faced difficulties before Algernon's suspicions. In order to prove his standing Jack told lies. Ultimately, he surrendered in front of Algernon. The most crucial point to Jack was his authentic identity. He confronted Lady Bracknell's interview boldly. He could say his present address, valid information about wealth and investment. But he could not utter his parents' name definitely. In fact, he had to face the most significant 
question who he actually is. Panza and Gregory argues, "Authenticity means living in a way that represents accurately who you are. This implies knowing the answer to a key question: Who am I?" (2008, p. 92). The playwright notes Jack's crisis:

I am afraid I really don't know. The fact is, Lady Bracknell, I said I had lost my parents. It would be nearer the truth to say that my parents seem to have lost me.... I don't actually know who I am by birth. I was... well, I was found (Wilde, 2016, p. 27).

To Jack, only authentic identity is the handbag where he has been found in the cloakroom of Victoria station. Lady Bracknell put a challenging question which intensely attacked Jack's self, "I would strongly advise you, Mr Wothing, to try and acquire some relations as soon as possible, and to make a definite effort to produce at any rate one parent, of either sex, before the season is quite over" (Wilde, 2016, p. 28). It was the hardest question for Jack to reply. He can produce a handbag anytime from anywhere. But he knows no machine which can produce a parent. Jack replied, "Well, I don't see how I could possibly manage to do that. I can produce the handbag at any moment. It is in my dressingroom at home. I really think that should satisfy you, Lady Bracknell" (Wilde, 2016, p. 28). But it is seen that Lady Bracknell was not satisfied with his answer. Instead, she argued:

Me, sir! What has it to do with me? You can hardly imagine that I and Lord Bracknell would dream of allowing our only daughter-a girl brought up with the utmost care-to marry into a cloak-room, and from an alliance with a parcel"(Wilde, 2016, p. 28).

The above statement indicates that Jack is nothing but a parcel. In order to get rid of this offensive charge, Jack discovered his self and real existence. At the end of the play, Jack creates an essence to prove his valid existence as human being. When he brought the handbag before Miss Prism, Jack asked:

Is this the hand-bag, Miss Prism? Examine it carefully before you speak. The happiness of more than one life depends on your answer (Wilde, 2016, p. 73).

Although Cecily Cardew is desperate in her fondness, disliking action, yet she cannot exceed the wall of Uncle Jack. She has enough worries about Uncle Jack. Cecily observed, "Dear Uncle Jack is so very serious! Sometimes he is so serious that I think he cannot be quite well" (Wilde, 2016, p. 34). She earnestly hopes that Mr. Jack will approve her will. The narrator noted Cecily's expectation, "I wish Uncle Jack would allow that unfortunate young man, his brother, to come down here sometimes. We might have good influence over him, Miss Prism" (Wilde, 2016, p. 35). When Lady Bracknell approved the marriage between Algernon and Cecily, Jack put his argument, "I beg your pardon for interrupting you, Lady Bracknell but this engagement is quite out of the question. I am Miss Cardew's guardian, and she cannot marry without my consent until she comes of age. That consent I absolutely decline to give" (Wilde, 2016, p. 68). During this conversation between Jack and Lady Bracknell, Cecily has to be silent. When Lady Bracknell urged her offer, Jack repeated his previous dialogue saying, "My own decision, however, is unalterable. I decline to give my consent" (Wilde, 2016, p. $69)$.

\subsection{Inauthenticity in Commitments and Religious Perception}

Jack Worthing gave self-contradicting comments which question the authenticity of his statements. He himself once thought that he was not fit for the name "Ernest", "Personally, darling, to speak quite candidly, I don't much care about the name of Ernest.... I don't think the name suits me at all" (Wilde, 2016, p. 23). But this Jack fluctuated from his own words at the end of the play. The narrator noted, "I always told you, Gwendolen, my name was Ernest, didn't I? Well, it is Ernest after all. I mean it naturally is Ernest" (Wilde, 2016, p. 76). In the very beginning of the play, Jack once falsely claimed that he had a younger brother named "Ernest". The playwright reported his acknowledgement:

In order to get up to town I have always pretended to have a younger brother name of Earnest, who lives in the Albany, and gets into the most dreadful scrapes. That, my dear Algy, is the whole truth pure and simple (Wilde, 2016, p. 17)

In a conversation with Gwendolen, Jack gave these following comments:

However, I will tell quite frankly that I have no brother Earnest. I have no brother at all. I never had a brother in my life, and I certainly have not the smallest intention of ever having one in the future" (Wilde, 2016, p. 57) 
When Lady Bracknell mentions that he is the son of her own sister Mrs. Moncrieff and Algernon is his younger brother, Jack changed his previous stand which proves his inauthenticity. Jack added, "I knew I had a brother! I always said I had a brother! Cecily-how could you have ever doubted that I had a brother? (Wilde, 2016, p. 74) These self-contradictory statement raises question about the validity, genuineness and authenticity of Jack's information. In the very beginning of the play, there remains inauthenticity of Algernon's words. He promised to prepare cucumber sandwiches for Lady Bracknell. A conversation between Lane and Algernon:

Algernon: And, speaking of the science of life, have you got the cucumber sandwiches for Lady Bracknell?

Lane: Yes, sir. [Hands them on a salver]

ALGERNON [Inspectes them, takes two, and sits down on the sofa] (Wilde, 2016, p. 11).

When Jack attempted to take one, Algernon stopped and suggested him bread and butter. The narrator notes:

[Jack puts out his hand to take a sandwich. AlGERNON at once interferces.] Please don't touch the cucumber sandwiches. They are ordered specially for Aunt Augusta. [Takes one and eats it.] (Wilde, 2016, p. 13).

Therefore, it is fair to be said that Algrnon prepared sandwiches for his aunt. Surprisingly, he changed his position later and denied the incident directly when Aunt Augusta reminded Algernon of the cucumber. The narrator pointed out Aunt Augusta's remark, "And now I'll have a cup of tea, and one of those nice cucumber sandwiches you promised me" Wilde, 2016, p. 20) In reply, Algernon mentioned that there remained no cucumber in the market:

ALGERNON: [picking up empty plate in horror]: Good heavens! Lane! Why are there no cucumber sandwiches? I ordered them specially.

LANE [gravely]: There were no cucumbers in the market this morning, sir. I went down twice.

ALGERNON: No cucumbers!

LANE: No, sir. Not even for ready money (Wilde, 2016, p. 20).

From these conversations, Algernon's inauthentic promise has been clearly proved.

Religion is always considered to be one of the sophisticated issues over the years. In this play, a different attitude towards religious values especially the process of Christening someone has been questioned. Since both Cecily and Gwendolen wanted to marry someone named "Ernest", therefore both Jack and Algernon began to face complicated situation. Finally, they decided to change their names as "Ernest". Dr. Chasuble reported, "Everything is quite ready for the christenings" (Wilde, 2016, p. 70). The reaction Lady Bracknell put up after knowing this fact was something different which questions the authenticity of Christening process, "The Christenings, sir! Is not that somewhat premature?" (Wilde, 2016, p. 71) Later, she gave the most crucial comments:

At their age? The idea is grotesque and irreligious! Algernon, I forbid you to be baptized. I will not hear such excuses. Lord Bracknell would be highly displeased if he learned that that the way in which you wasted your time and money" (Wilde, 2016, p. 71).

\subsection{The Name "Earnest": Authentic or Inauthentic}

The name "Earnest" has strong and visible influence throughout the entire play. In fact, this single word is considered to be the core issue which haunts both Jack and Algernon until the end. Like Gwendolen, Cecily had been strictly motivated by this name. This incident raises question of how a name can be so powerful and authentic. The play shows in what degree of love Jack holds for Gwendolen. The narrator noted Jack's first impression, "Miss Fairfax, ever since I met you I have admired you more than any girl...I have ever met since...I met you" (Wilde, 2016, p.22). Gwendolen knows Jack's dedication and demonstration. The playwright remarked, "For me you have always had an irresistible fascination. Even before I met you I was far from indifferent to you" (Wilde, 2016, p. 22). Even then, she is more interested in the name "Ernest" as it has been mentioned frequently in monthly magazines. In order to show her ground, Gwendolen explained her ideal, "and my ideal has been to love someone of the name of Ernest. There is something in that name that inspires absolute confidence" (Wilde, 2016, p. 22). It means that name is more important than the valid human actions. Gwendolen admitted, "The moment Algernon first mentioned to me that he had a friend called Ernest, I knew I was destined to love you" (Wilde, 2016, p. 22). Additionally, Gwendolen thinks that Jack 
was perfectly suitable for this name "Earnest". As part of her grounding argument, she put her comments towards Jack, "It suits you perfectly. It is a divine name. It has music of its own. It produces vibrations" (Wilde, 2016, p. 23). Yet Jack tried to convince her other ways that they might have more suitable names, "Well, really, Gwendolen, I must say that I think there are lots of other much nicer names. I think Jack, for instance, a charming name" (Wilde, 2016, p. 23). Stating these words, Jack wanted to legitimize his real name. But Gwendolen argued, "Jack?... No, there is very little music in the name Jack, if any at all, indeed. It does not thrill. It produces absolutely no vibrations ... I have known several Jacks, and they all, without exception, were more than usually plain" (Wilde, 2016, p. 23). But there goes a proverb that a tree is known by its fruits. Therefore, a man needs to be judged on the basis of his/her actions. Here in this play, both Cecily and Gwendolen want to judge somebody by the name. This incident creates question about the authenticity of this judgment.

To Jack, the name Earnest has no particular significance. He is using this only to impress Gwendolen, "I'm not a Bunburyist at all. If Gwendolen accepts me, I am going to kill my brother, indeed I think I'll kill him in any case" (Wilde, 2016, p. 18). On the other hand, Lady Bracknell took an interview to know details about Jack including social and economic background. Even, Gwendolen claims that the name "Earnest" has close connection with security issues, "The only really safe name is Ernest" (Wilde, 2016, p. 23). In order to check Gwendolen's interest, Jack fundamentally asked, "But you don't really mean to say that you couldn't love me if my name wasn't Ernest?" Gwendolen did not reply directly rather she emphasized, "But your name is Ernest" (Wilde, 2016, p. 23). This indirect answer proves that name is more important than the person.

Algernon had same experience with Cecily. To her, the name Earnest is something like a dream. The playwright noted Cecily understands:

You must not laugh at me, darling, but it had always been a girlish dream of mine to love someone whose name was Earnest. ....There is something in that name that seems to inspire absolute confidence. I pity any poor married woman whose husband is not called Earnest (Wilde, 2016, p. 49).

Later, Algernon tasted Cecily putting a direct question. The conversation is:

ALGERNON: But, my dear child, do you mean to say you could not love me if I had some other name?

CECILY: But what name?

ALGERNON: Oh, any name you like- Algernon-for instance...

CECILY: But I don't like the name Algernon (Wilde, 2016, p. 49).

Both Jack and Algernon know that they are using a fake name. It does not make any sense. Jack's advice to Algernon proves the inauthenticity of this name clearly, "So I am going to get rid of Earnest. And I strongly advise you to do the same with Mr... with your invalid friend who has had the absurd name" (Wilde, 2016, p.18). Both Jack and Algernon could question the authenticity of the names "Cecily" and "Gwendolen" the way they faced crisis and urge to change their names so urgently. But they did not look for that as they knew that names were nothing but words. But to Gwendolen and Cecily, the name "Earnest" has particular significance, confidence and security. On the other hand, Jack and Algernon think that the importance of any particular name is illogical, inauthentic and absurd. Until the last moment they were known as Jack and Algernon. At the end, they discovered the name "Earnest". Therefore, the previous name and the current one refers to the same person.

\section{CONCLUSION}

Due to the restrictions of Victorian society, it may be logical to think that Jack and Algernon have been encouraged to generate their false personalities on the way to search the self, ample freedom and choice. While Algernon is desperate and tyrannical in motivation and action, Jack is not happy with his inauthentic identity. If the society provided flexible environment in terms of religious ideals, values and practices, they would not initiate untrue characters. Moreover, the baptism process turned into a commercial form intentionally which affected their religious perception.

Gwendolen and Cecily had profound attention towards the name "Earnest" from the very beginning. In the course of time, they began to lose their interest and finally distracted both Jack and Algernon from the upcoming naming session. Therefore, their demand for the name "Earnest" was inauthentic. Besides, Jack and Algernon tried to set the truth that the name "Earnest" has no particular 
value. Like Gwendolen and Cecily, they could remain constant to their point. Throughout the entire play, Jack claims that he has no brother and even there remains no possibility in future. Surprisingly, this same Jack fluctuated from his previous stand and commitments when he discovered his original name "Earnest".

To some extent, the name "Earnest" may be relevant in the sense that most of the incidents of the play have been focused on this single name. Later, the complaint goes to the phrase "The Importance". Naturally, every entity, either living or non-living, needs a name so that it can be separated from others. But it does not mean that a particular name will be a parameter of evaluation. For centuries, man has been assessed based on individual characteristics, contributions and efficiency. Moreover, Lady Bracknell always demanded Jack's valid parental information. She never put her interest on the name "Earnest" rather she expected at least one specific name either mother or father. Interestingly, Jack could not avail this simple information. As a result, Lady Bracknell rejected his proposal. It means that no importance has been implied on the name "Earnest".

In one sense, if both Gwendolen and Cecily remained uncompromising until the end, if both Jack and Algernon changed their entity finally, then the significance of "The Importance" would be authentic. If the "Handbag" mystery revealed a different name of Jack apart from "Earnest", Lady Bracknell would accept since she had concentration on Jack's valid parental information. Therefore, it will not be exaggeration to say that "Being Earnest" makes no particular sense or importance in the play.

\section{REFERENCES}

Barris, Jeremy. (2008). The formal structure of metaphysics and The Importance of Being Ernest. Blackwell Publishing Ltd., 39(4-5), 546-570.

Carman, Taylor. (2006). The concept of authenticity. A Companion to Phenomenology and Existentialism. Edited by Hubert L. Dreyfus and Mark A. Blackwell Publishing, 229-239.

Flynn, Thomas R. (2006). Existentialism: A very short introduction. Oxford University Press.

Garland, Tony W. (2012). The contest of naming between ladies in the Importance of Being Ernest". Routledge, 70(4), 272-274. doi: 10.1080/00144940.2012.727893

Lalonde, Jeremy. (2005). A "Revolutionary Outrage": The Importance of Being Earnest as Social Criticism. Modern Drama(University of Toronto Press), 48(4), 569-676. doi: 10.1353/mdr.2006.0032

Macquarrie, John. (1973). Existentialism. Penguin Books.

Nassaar, Christopher. (2002). Wilde's The Importance of Being Ernest. The Explicator, 60 (2), 78-80. DOI: $10.1080 / 00144940209597662$.

Panza, Christopher, \& Gale, Gregory. (2008). Existentialism for Dummies. Wiley Publishing.

Shabir, Junaid Shah. (2020). Oscar Wilde's 'The Importance of Being Earnest' as a caricature of victorian England. Contemporary Literary Review India, 7(3), 80-90.

Wilde, Oscar. (2016). The Importance of Being Ernest. Penguin Books.

\section{AUTHORS' BIO}

Md. Ibrahim Khalil is Lecturer of the Department of English at Pabna University of Science and Technology, Pabna-6600, Bangladesh. He is interestd in South Asian Literature and Translation Studies. 